\title{
Development and Demonstrational Instantiation of a Method for the Structured Content Analysis of Smartphone Apps
}

\author{
Tobias Weiss* and Susanne Strahringer \\ Chair of Information Systems, esp. IS in Manufacturing and Commerce, \\ Technische Universität Dresden, 01062 Dresden, Germany \\ tobias.weiss@tu-dresden.de, susanne.strahringer@tu-dresden.de
}

\begin{abstract}
The publication discusses the adaptation of dedicated known methods for structured content analysis for the usage of smartphone apps, taking into account the specifics of these dynamic media types and resulting consequences for the procedure and content rating. The background is the increasing popularity of apps and the growing demand for precise analysis of the status quo regarding the content and functions of apps on the market, especially within design-oriented business informatics. Within the literature, no uniform, comparable and systematic approach to this could be identified so far. Therefore, an existing standard for the evaluation of apps from the medical context has been adapted for general application to apps. This provides a helpful procedure for researchers, practitioners, and students and ensures consistency across studies. The feasibility of the proposed method and assessment standard were confirmed by a successful demonstrational instantiation based on an app review of energy information systems for private customers.
\end{abstract}

Keywords: Method, Procedure, Content Analysis, Evaluation, Smartphone Apps.

\section{Introduction}

Smartphones and related apps are constantly increasing in popularity. For years the distribution within the population has been growing steadily across all age groups, and there is still potential in developing nations. We can observe the currently highest smartphone penetration rate with nearly $82 \%$ in the US, followed by European countries, for instance, the UK with $79 \%$ and Germany with $78 \%$ [1]. The rate is even higher in specific age groups, such as over $95 \%$ of the 14 to 49 age group in Germany [2]. As of Q1/2021, approximately 3.5 million (Google Play Store) and 2.2 million (Apple App Store) apps were available for download in the leading App Stores, by Google and Apple [3]. The Windows and Amazon stores are, with over 1 million apps, increasingly relevant as well. This means that there is a strong basis in terms of smartphone distribution in all relevant markets and their applicability for economic and scientific purposes, in

\footnotetext{
* Corresponding author
}

(C) 2021 Tobias Weiss and Susanne Strahringer. This is an open access article licensed under the Creative Commons Attribution License (http://creativecommons.org/licenses/by/4.0).

Reference: T. Weiss and S. Strahringer, "Development and Demonstrational Instantiation of a Method for the Structured Content Analysis of Smartphone Apps,” Complex Systems Informatics and Modeling Quarterly, CSIMQ, no. 28, pp. 15-33, 2021. Available: https://doi.org/10.7250/csimq.2021-28.02

Additional information. Author's ORCID iD: S. Strahringer - orcid.org/0000-0002-9465-9679, PII S225599222100160X. Received: 4 October 2021. Accepted: 25 October 2021. Available online: 31 October 2021. 
which significant investments are made [4]. Apps are thus to be preferred for many applications that are intended to reach end-users, also due to their technical features (e.g., mobile availability, enabling various forms of communication; push suitability; and a broad multimedia spectrum). This is also in line with the ongoing research for mobile-only adoption, also in households with age 55+ [5]. Even in very sensitive areas, such as finance and banking, which are sometimes characterized by user restraint, the literature observes a rapid increase in user acceptance [6]. In general, smartphones and apps are seen as a potentially very useful way of delivering information to interested parties - regardless of time and place [4], [7].

Need for research. In terms of the rapid spread of smartphone apps and their applications in the economy, there is a growing need for their analysis. Analogous to other types of media (e.g. online content or TV artifacts), which have been systematically analyzed within the literature, a researcher needs to get an overview of existing implementations in advance [8], [9]. For instance, this overview of extracted functions and features of apps is highly interesting for the development of a new app or an app prototype by researchers. Especially, this is relevant for a successful application of the design science research methodology for modern information systems research, as stated within the common framework descriptions. As it is essential to start with a complete picture of the environment and ideally build on existing research, the method of content analysis is one option to achieve this (within the context of systematic reviews) [10]-[13].

Generic methods are available for this purpose, but they do not yet address the specifics of a digital, fast-moving environment and the media type "smartphone apps" in a proper scope. Thus, a researcher is currently required to carry out comprehensive research and transfer those methods within several iterations. We could not identify any generalized and holistic approach to analyze smartphone app content. This gap is also confirmed by the results of a systematic literature review, as presented in Section 2. In addition to this, statements within the literature explicitly describe the difficulty for users and researchers to identify and evaluate apps:

- "There is a large and ever-increasing number of mobile phone health, wellness, and medical applications on the market. However, there is little guidance or quality assurance available for consumers. " [14];

- "(...) there is no consensus on the use of any specific methodology for evaluating apps (...)" [15];

- "Given the rapid proliferation of smart phone apps, it is increasingly difficult for users, health professionals, and researchers to readily identify and assess high quality apps (...)", "Little information on the quality of apps is available, beyond the star ratings published on retailers' Web pages, and app reviews are subjective by nature and may come from suspicious Sources (...)", "Previous attempts to develop mobile app evaluation criteria have been too technical or specific (...)” [16].

This shows that the procedures described in the common literature for content analysis cannot be fully adapted to smartphone apps without limitations. Little useful documentation is accessible, especially regarding the assessment of the user-perceived quality of apps. In many cases, app store ratings (in text form and aggregated as star ratings) are the only form of user perception which is available for further analysis. Furthermore, these ratings are sometimes alienated by subjectivity [16]-[18]. To sum it up no applicable recommendation for a systematic content analysis of apps could be identified for the field of business informatics. This circumstance leads to the research question: How must an existing method for content analysis be adapted to the specifics of smartphone apps so that a comprehensible, transparent and systematic content analysis can be performed by a researcher?

Research goal. Thus, we aim to provide a method description for performing content analysis based on the specific media type "smartphone app" to fill the identified need. This should offer:

a) An applicable, in particular to the design-science-oriented business informatics research, procedure for content analysis of smartphone apps. 
b) A standardized set of criteria for the time-efficient, initial evaluation of features of the apps ensuring their comparability.

The development of the method itself is guided by established procedures as stated by the literature providing a generic framework as a guidance instrument, checklist, and tool for quality control [19], [20]. Our contributions can, therefore, be formulated as follows:

c) Overview of literature on methods of content analysis regarding smartphone apps;

d) Derivation of a systematic approach for the content analysis of smartphone apps;

e) Transformation of domain-specific evaluation categories for general application to apps.

Overview. The article is structured as follows: Within Section 2, the basis for the development of the method is compiled from the literature. In Section 3, the design of the analysis procedure is presented as well as the suggested set of criteria for the evaluation of apps. This is mainly derived from literature and integrates different features of the highly dynamic media type "smartphone app". Section 4 describes the evaluation of the method as demonstrational instantiation based on a real use case (identification of functional components of apps in the field of energy feedback systems). The whole research is based mainly on method creation guidelines, e.g., [19] and underlying literature for content analysis.

\section{Related Work}

\subsection{Content Analysis in General}

The procedures for performing a content analysis are well documented in the established international literature. In many cases, those guidelines follow similar premises and steps. To conduct a content analysis based on very dynamic digital media types (smartphone apps), we identified the limitation of the procedures to classical media, e.g., textual artifacts, and a lack of guidance for researchers. Although content analysis should be "applicable to all contexts" [9] there is a more active and participatory role of the user compared to traditional media. As a result, smartphone apps are not time-stable and, therefore, unsuitable for multilevel, comprehensive coding procedures. The volatility of these new media types results in several difficulties: during the feature extraction process, during coding, and documentation. One example: When using search engines to identify the units of the content analysis, the influence of algorithms in the weighting of the display or sorting can make reproducibility difficult, and many elements of the object can be left undetected [9], [21].

However, the basis for the analysis lies in the established methods, serving as an estimation of the distribution of certain characteristics/features. This can be conducted via a simple counting procedure of the relevant characteristics. Either based on all available analysis objects (complete survey) or for an extract (sample). The literature differentiates between qualitative and quantitative content analysis, as well as "mixed methods" such as the integrative content analysis. The common approach for content analysis described within the literature, [8], [9], [21]-[25], is further used as a basis for the following research process in this article.

In the following, we will examine whether there is any specific documentation in scientific publications on content analysis of smartphone apps.

\subsection{Status Quo within the Content Analysis of Smartphone Apps}

The goal of this initial literature search is to find a possible solution for the initially formulated need for research: a usable method to systematically analyze smartphone apps and document the features. The search terms (content analysis OR Content Analysis) AND (Apps OR SmartphoneApps) were used in scientific search engines "Elsevier ScienceDirect", "ResearchGate", "SpringerLink" and "Google Scholar". The overview of relevant works is documented in Table 1. 
Table 1. Results of the literature analysis

\begin{tabular}{|c|c|c|c|c|c|c|c|c|c|c|}
\hline 冚 & $\stackrel{\varrho}{\stackrel{E}{E}}$ & 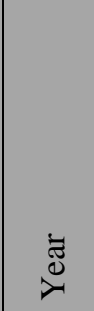 & 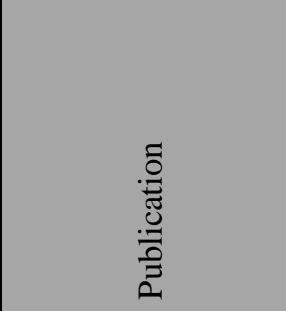 & 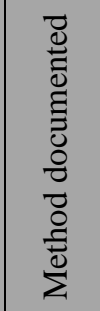 & 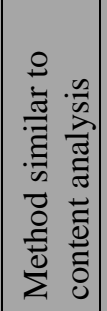 & 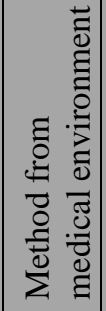 & 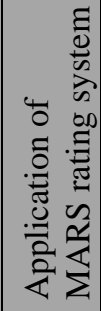 & 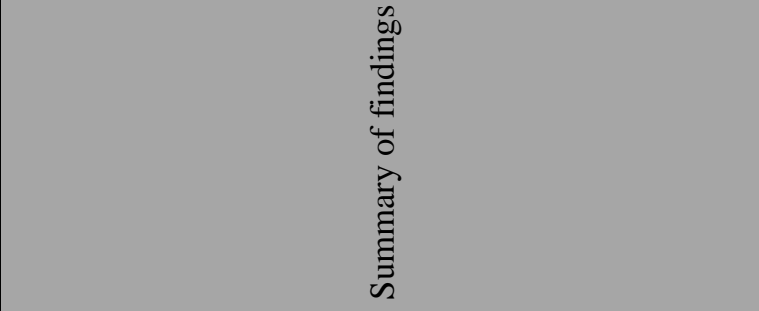 & 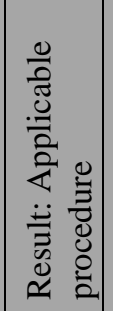 & .0 \\
\hline $\begin{array}{l}\text { Abroms } \\
\text { et al. }\end{array}$ & $\begin{array}{l}\text { A Content Analysis of Popular Smartphone } \\
\text { Apps for Smoking Cessation }\end{array}$ & 2013 & $\begin{array}{l}\text { American Journal } \\
\text { of Preventive } \\
\text { Medicine }\end{array}$ & NO & $\mathrm{NO}$ & $\mathrm{NO}$ & $\mathrm{NO}$ & $\begin{array}{l}\text { Apps were coded (adherence index and generic } \\
\text { information, like the number of downloads and user } \\
\text { rating). No specific method or procedure } \\
\text { documentation was referenced. }\end{array}$ & NO & [26] \\
\hline $\begin{array}{l}\text { Alessa } \\
\text { et al. }\end{array}$ & $\begin{array}{l}\text { Smartphone Apps to Support Self- } \\
\text { Management of Hypertension: Review and } \\
\text { Content Analysis }\end{array}$ & 2019 & $\begin{array}{l}\text { JMIR mHealth and } \\
\text { uHealth }\end{array}$ & NO & $\mathrm{NO}$ & NO & NO & No method was referenced. & NO & [32] \\
\hline $\begin{array}{l}\text { Azar et } \\
\text { al. }\end{array}$ & $\begin{array}{l}\text { Mobile Applications for Weight } \\
\text { Management }\end{array}$ & 2013 & $\begin{array}{l}\text { American Journal } \\
\text { of Preventive } \\
\text { Medicine }\end{array}$ & YES & NO & NO & NO & $\begin{array}{l}\text { Conducted a comparative, descriptive assessment of } \\
\text { smartphone apps. Evaluation with different criteria } \\
\text { and categories, according to classical behavioral } \\
\text { theory and fogg behavioral model. }\end{array}$ & NO & [33] \\
\hline $\begin{array}{l}\text { Bowie- } \\
\text { DaBreo } \\
\text { et al. }\end{array}$ & $\begin{array}{l}\text { A content analysis and ethical review of } \\
\text { mobile applications for depression: } \\
\text { Exploring the app marketplace } \\
\end{array}$ & 2019 & N/A & NO & NO & NO & NO & $\begin{array}{l}\text { Content analysis and review with key categories } \\
\text { (ratings, treatment information, usage data etc.), but } \\
\text { with no clear reference to a usable method. }\end{array}$ & NO & [34] \\
\hline $\begin{array}{l}\text { Bry et } \\
\text { al. }\end{array}$ & $\begin{array}{l}\text { Consumer Smartphone Apps Marketed for } \\
\text { Child and Adolescent Anxiety: A } \\
\text { Systematic Review and Content Analysis } \\
\end{array}$ & 2018 & Behavior Therapy & NO & NO & NO & NO & $\begin{array}{l}\text { Coding of the identified top apps based on general } \\
\text { information, functions etc. No specific method } \\
\text { reference. }\end{array}$ & $\mathrm{NO}$ & [35] \\
\hline $\begin{array}{l}\text { Ferriero } \\
\text { et al. }\end{array}$ & $\begin{array}{l}\text { Apps for smartphone available through } \\
\text { distribution platforms and validated for } \\
\text { goniometric measurement: A systematic } \\
\text { review }\end{array}$ & 2018 & $\begin{array}{l}\text { Annals of Physical } \\
\text { and Rehabilitation } \\
\text { Medicine }\end{array}$ & NO & NO & NO & NO & Systematic review, no reference to a usable method. & NO & [36] \\
\hline $\begin{array}{l}\text { Hoeppn } \\
\text { er et al. }\end{array}$ & $\begin{array}{l}\text { There is an app for that - Or is there? A } \\
\text { content analysis of publicly available } \\
\text { smartphone apps for managing alcohol use }\end{array}$ & 2017 & \begin{tabular}{|l|} 
Journal of \\
Substance Abuse \\
Treatment \\
\end{tabular} & NO & NO & NO & NO & $\begin{array}{l}\text { Content analysis without method reference of } \\
\text { android apps, and coding based on basic descriptors, } \\
\text { functions and features. }\end{array}$ & NO & [27] \\
\hline $\begin{array}{l}\text { Hotwani } \\
\text { et al. }\end{array}$ & $\begin{array}{l}\text { Smartphones and tooth brushing: content } \\
\text { analysis of the current available mobile } \\
\text { health apps for motivation and training }\end{array}$ & 2020 & $\begin{array}{l}\text { European Archives } \\
\text { of Pediatric } \\
\text { Dentistry }\end{array}$ & NO & NO & YES & NO & $\begin{array}{l}\text { Used CALO-RE as a framework for coding } \\
\text { (taxonomy for behavior change) }\end{array}$ & NO & [28] \\
\hline
\end{tabular}


Table 1. Continued

\begin{tabular}{|c|c|c|c|c|c|c|c|c|c|c|}
\hline 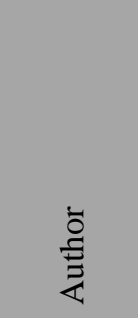 & $\stackrel{\varrho}{\stackrel{E}{E}}$ & $\stackrel{\varpi}{\beth}$ & 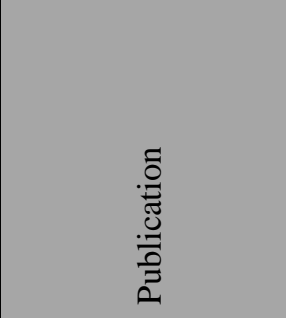 & 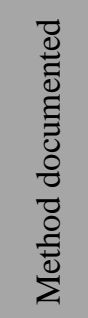 & 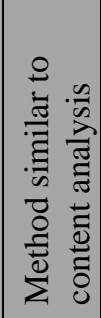 & 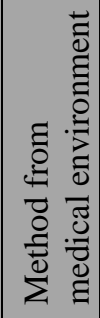 & 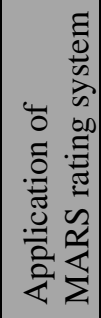 & 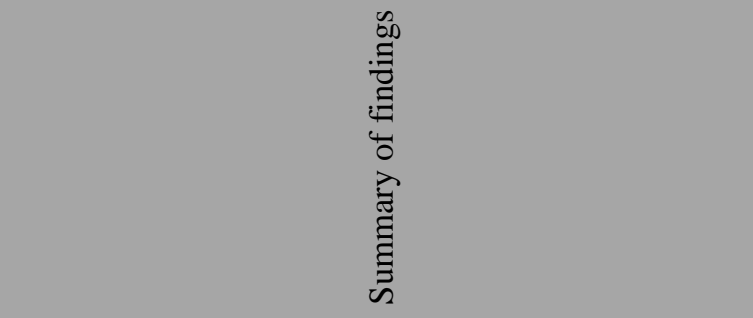 & 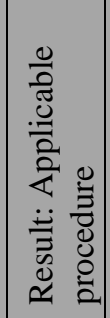 & 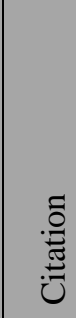 \\
\hline $\begin{array}{l}\text { Linardo } \\
\mathrm{n}, \mathrm{J} .\end{array}$ & $\begin{array}{l}\text { Can Acceptance, Mindfulness, and Self- } \\
\text { Compassion Be Learned by Smartphone } \\
\text { Apps? A Systematic and Meta-Analytic } \\
\text { Review of Randomized Controlled Trials }\end{array}$ & 2020 & Behavior Therapy & YES & NO & $\mathrm{NO}$ & NO & Literature based investigation, no method reference. & NO & {$[37]$} \\
\hline $\begin{array}{l}\text { Maxwell } \\
\text { et al. }\end{array}$ & $\begin{array}{l}\text { A Content Analysis of Personal Safety } \\
\text { Apps: Are They Keeping Us Safe or } \\
\text { Making Us More Vulnerable? }\end{array}$ & 2019 & $\begin{array}{l}\text { Violence Against } \\
\text { Women }\end{array}$ & NO & NO & NO & NO & $\begin{array}{l}\text { Coding with available elements of the apps, no } \\
\text { specific method was referenced. }\end{array}$ & NO & {$[38]$} \\
\hline $\begin{array}{l}\text { Middel } \\
\text { weerd et } \\
\text { al. }\end{array}$ & $\begin{array}{l}\text { Apps to promote physical activity among } \\
\text { adults: a review and content analysis }\end{array}$ & 2014 & $\begin{array}{l}\text { International } \\
\text { Journal of } \\
\text { Behavioral } \\
\text { Nutrition and } \\
\text { Physical Activity } \\
\end{array}$ & YES & NO & NO & NO & $\begin{array}{l}\text { Review of apps based on the taxonomy of behavior } \\
\text { change. Quantitative analysis of the findings. }\end{array}$ & NO & [39] \\
\hline Qari, A. & $\begin{array}{l}\text { Assessing the quality of mobile apps for } \\
\text { oral health: content analysis and usability }\end{array}$ & 2020 & N/A & YES & NO & YES & NO & $\begin{array}{l}\text { Identification of keywords per Google Trends, as no } \\
\text { scientific method for keyword identification was } \\
\text { known. Selection according to PRISMA guidelines } \\
\text { as a systematic review method. }\end{array}$ & NO & [29] \\
\hline $\begin{array}{l}\text { Shuler, } \\
\text { C. }\end{array}$ & $\begin{array}{l}\text { A Content Analysis of the iTunes App } \\
\text { Store's Education Section }\end{array}$ & 2009 & N/A & NO & NO & NO & NO & $\begin{array}{l}\text { Basic coding of the apps, no specific method } \\
\text { referenced. }\end{array}$ & NO & {$[40]$} \\
\hline $\begin{array}{l}\text { Tham et } \\
\text { al. }\end{array}$ & $\begin{array}{l}\text { A content analysis of popular diet, fitness, } \\
\text { and weight self-tracking mobile apps on } \\
\text { Google Play }\end{array}$ & 2020 & $\begin{array}{l}\text { iConference } 2020 \\
\text { Proceedings }\end{array}$ & NO & NO & $\mathrm{NO}$ & NO & $\begin{array}{l}\text { Content analysis according to features based on } \\
\text { research questions. No specific method referenced. }\end{array}$ & NO & [41] \\
\hline $\begin{array}{l}\text { Charbon } \\
\text { neau et } \\
\text { al. }\end{array}$ & $\begin{array}{l}\text { Smartphone apps for cancer: A content } \\
\text { analysis of the digital health marketplace }\end{array}$ & 2020 & $\begin{array}{l}\text { DIGITAL } \\
\text { HEALTH }\end{array}$ & YES & NO & $\mathrm{NO}$ & NO & $\begin{array}{l}\text { Application characteristics (like price, platform, } \\
\text { purpose of the app etc.) were collected, analyzed, } \\
\text { and reported. No specific method or procedure } \\
\text { documentation was referenced. }\end{array}$ & NO & [42] \\
\hline $\begin{array}{l}\text { West et } \\
\text { al. }\end{array}$ & $\begin{array}{l}\text { There's an App for That: Content Analysis } \\
\text { of Paid Health and Fitness Apps }\end{array}$ & 2012 & $\begin{array}{l}\text { Journal of Medical } \\
\text { Internet Research } \\
\end{array}$ & YES & YES & YES & $\mathrm{NO}$ & $\begin{array}{l}\text { Usage of the Precede-Proceed-Model (PPM) as a } \\
\text { framework for the coding. }\end{array}$ & $\mathrm{NO}$ & [43] \\
\hline
\end{tabular}


Table 1. Continued

\begin{tabular}{|c|c|c|c|c|c|c|c|c|c|c|}
\hline 冚 & $\stackrel{\varrho}{D}$ & 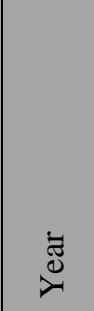 & 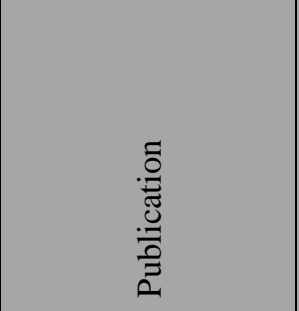 & 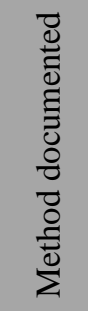 & 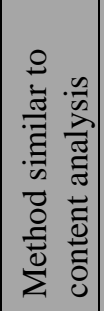 & 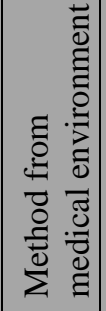 & 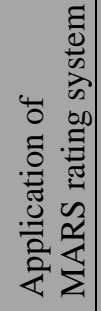 & 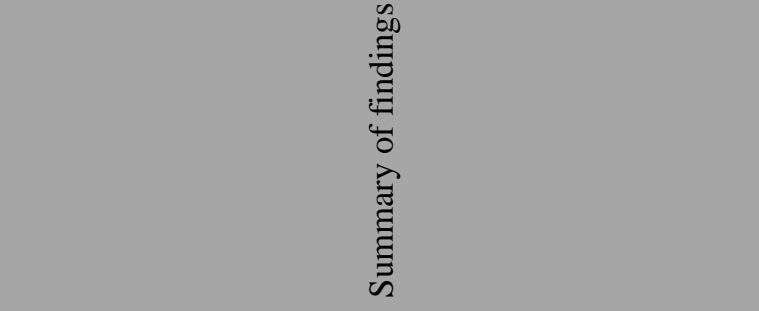 & 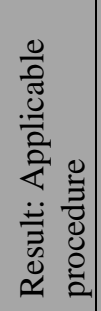 & . \\
\hline $\begin{array}{l}\text { Zaidan, } \\
\text { S.; } \\
\text { Roehrer, } \\
\text { E. }\end{array}$ & $\begin{array}{l}\text { Popular Mobile Phone Apps for Diet and } \\
\text { Weight Loss: A Content Analysis }\end{array}$ & 2016 & $\begin{array}{l}\text { JMIR mHealth and } \\
\text { uHealth }\end{array}$ & YES & YES & YES & $\mathrm{NO}$ & $\begin{array}{l}\text { Content analysis with study design documented, } \\
\text { referenced methods from medical environment. }\end{array}$ & $\mathrm{NO}$ & [44] \\
\hline $\begin{array}{l}\text { Coulon } \\
\text { et al. }\end{array}$ & $\begin{array}{l}\text { A Systematic, Multi-domain Review of } \\
\text { Mobile Smartphone Apps for Evidence- } \\
\text { Based Stress Management }\end{array}$ & 2016 & $\begin{array}{l}\text { American Journal } \\
\text { of Preventive } \\
\text { Medicine }\end{array}$ & YES & YES & $\mathrm{NO}$ & $\mathrm{NO}$ & $\begin{array}{l}\text { Used a methodology as orientation for the review } \\
\text { process, documented levels and criteria for the } \\
\text { inclusion of identified apps. }\end{array}$ & $\mathrm{NO}$ & [15] \\
\hline $\begin{array}{l}\text { Fernand } \\
\text { ez- } \\
\text { Luque et } \\
\text { al. }\end{array}$ & $\begin{array}{l}\text { Content Analysis of Apps for Growth } \\
\text { Monitoring and Growth Hormone } \\
\text { Treatment: Systematic Search in the } \\
\text { Android App Store }\end{array}$ & 2020 & $\begin{array}{l}\text { JMIR mHealth and } \\
\text { uHealth }\end{array}$ & YES & YES & NO & $\mathrm{NO}$ & $\begin{array}{l}\text { Semi-automated search with a search engine. Apps } \\
\text { categorized by target audience, type, additional } \\
\text { aspects etc. Presentation of the search as tree model. } \\
\text { No specific method was referenced. }\end{array}$ & $\mathrm{NO}$ & [45] \\
\hline $\begin{array}{l}\text { Nicholas } \\
\text { et al. }\end{array}$ & $\begin{array}{l}\text { The Reviews Are in: A Qualitative Content } \\
\text { Analysis of Consumer Perspectives on } \\
\text { Apps for Bipolar Disorder }\end{array}$ & 2017 & $\begin{array}{l}\text { Journal of Medical } \\
\text { Internet Research }\end{array}$ & $\mathrm{NO}$ & YES & $\mathrm{NO}$ & $\mathrm{NO}$ & $\begin{array}{l}\text { Investigation of app reviews with qualitative content } \\
\text { analysis of the texts. No reference to a specific } \\
\text { method. }\end{array}$ & $\mathrm{NO}$ & [46] \\
\hline $\begin{array}{l}\text { Payne et } \\
\text { al. }\end{array}$ & $\begin{array}{l}\text { A content analysis of precede-proceed } \\
\text { constructs in stress management mobile } \\
\text { apps }\end{array}$ & 2016 & mHealth & YES & YES & YES & NO & $\begin{array}{l}\text { Application of qualitative content analysis. Usage of } \\
\text { Precede-Proceed Model (PPM) for coding. }\end{array}$ & NO & [47] \\
\hline $\begin{array}{l}\text { Robinso } \\
\text { n et al. }\end{array}$ & $\begin{array}{l}\text { A content analysis of smartphone apps for } \\
\text { adolescent smoking cessation }\end{array}$ & 2018 & $\begin{array}{l}\text { Translational } \\
\text { Behavioral } \\
\text { Medicine }\end{array}$ & $\mathrm{NO}$ & YES & $\mathrm{NO}$ & $\mathrm{NO}$ & $\begin{array}{l}\text { Coding of the apps based on literature and regular } \\
\text { information, extraction of main functions of the } \\
\text { apps. Documentation of the search process. No } \\
\text { reference to a specific method. }\end{array}$ & NO & [48] \\
\hline $\begin{array}{l}\text { Shen et } \\
\text { al. }\end{array}$ & $\begin{array}{l}\text { Finding a Depression App: A Review and } \\
\text { Content Analysis of the Depression App } \\
\text { Marketplace }\end{array}$ & 2015 & $\begin{array}{l}\text { JMIR mHealth and } \\
\text { uHealth }\end{array}$ & NO & YES & $\mathrm{NO}$ & NO & $\begin{array}{l}\text { Execution of a systematic review. Documentation of } \\
\text { search results and coding scheme, but no reference } \\
\text { to underlying method. }\end{array}$ & NO & [49] \\
\hline $\begin{array}{l}\text { Wasil et } \\
\text { al. }\end{array}$ & $\begin{array}{l}\text { A review of popular smartphone apps for } \\
\text { depression and anxiety: Assessing the } \\
\text { inclusion of evidence-based content }\end{array}$ & 2019 & $\begin{array}{l}\text { Behaviour } \\
\text { Research and } \\
\text { Therapy }\end{array}$ & $\mathrm{NO}$ & YES & $\mathrm{NO}$ & $\mathrm{NO}$ & $\begin{array}{l}\text { Analysis of all available apps vs. top apps, definition } \\
\text { of inclusion and exclusion criteria, development of a } \\
\text { codebook with } 26 \text { elements. }\end{array}$ & $\mathrm{NO}$ & [50] \\
\hline
\end{tabular}


Table 1. Continued

\begin{tabular}{|c|c|c|c|c|c|c|c|c|c|c|}
\hline 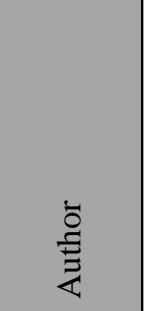 & $\stackrel{\varrho}{D}$ & 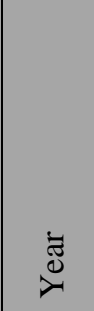 & 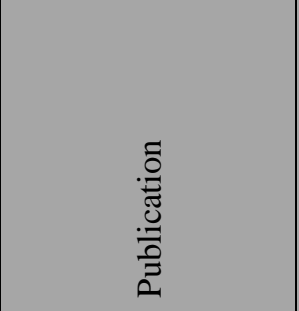 & 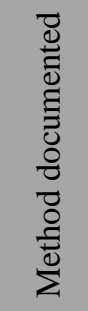 & 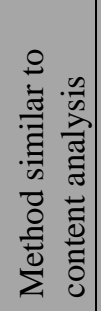 & 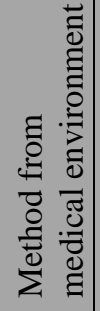 & 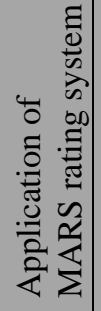 & 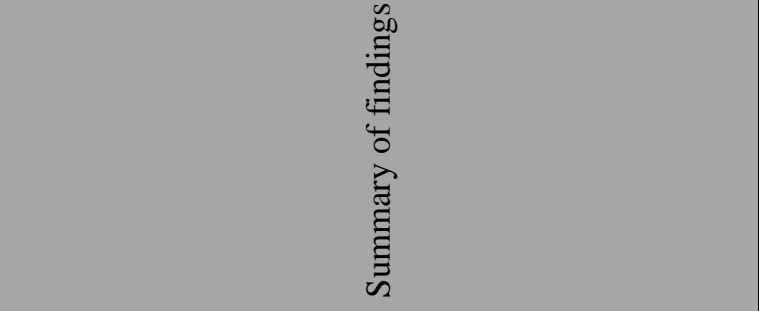 & 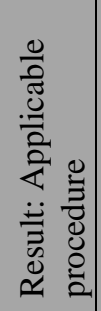 & 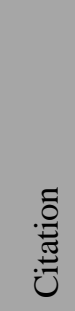 \\
\hline $\begin{array}{l}\text { Xu, Y.; } \\
\text { Warscha } \\
\text { uer, M. }\end{array}$ & $\begin{array}{l}\text { A Content Analysis of Voice-based Apps } \\
\text { on the Market for Early Literacy } \\
\text { Development }\end{array}$ & 2020 & $\begin{array}{l}\text { IDC'20: } \\
\text { Proceedings of the } \\
\text { Interaction Design } \\
\text { and Children } \\
\text { Conference } \\
\end{array}$ & YES & YES & $\mathrm{NO}$ & $\mathrm{NO}$ & $\begin{array}{l}\text { Developed criteria catalog for content analysis, but } \\
\text { no specific method was referenced. }\end{array}$ & $\mathrm{NO}$ & [51] \\
\hline $\begin{array}{l}\text { Machad } \\
\text { o et al. }\end{array}$ & $\begin{array}{l}\text { Smartphone apps for the self-management } \\
\text { of low back pain: A systematic review }\end{array}$ & 2016 & $\begin{array}{l}\text { Best Practice \& } \\
\text { Research Clinical } \\
\text { Rheumatology }\end{array}$ & YES & YES & YES & YES & $\begin{array}{l}\text { Systematic review according to PRISMA } \\
\text { recommendations, extraction of generic information } \\
\text { (cost, platform, reviews etc.) and a specific } \\
\text { taxonomy. }\end{array}$ & $\mathrm{NO}$ & [30] \\
\hline $\begin{array}{l}\text { Biviji et } \\
\text { al. }\end{array}$ & $\begin{array}{l}\text { Content analysis of behavior change } \\
\text { techniques in maternal and infant health } \\
\text { apps }\end{array}$ & 2020 & $\begin{array}{l}\text { Translational } \\
\text { Behavioral } \\
\text { Medicine }\end{array}$ & YES & NO & YES & YES & $\begin{array}{l}\text { Used MARS for assessment and taxonomy for } \\
\text { screening procedure. No reference to content } \\
\text { analysis method. }\end{array}$ & $\mathrm{NO}$ & [52] \\
\hline $\begin{array}{l}\text { Lee et } \\
\text { al. }\end{array}$ & $\begin{array}{l}\text { A content analysis of free smoking } \\
\text { cessation mobile applications in the USA }\end{array}$ & 2019 & \begin{tabular}{|l|} 
Journal of \\
Smoking Cessation
\end{tabular} & YES & $\mathrm{NO}$ & YES & YES & $\begin{array}{l}\text { Defined top apps from search volume, categorization } \\
\text { based on MARS framework. Solid methodology, but } \\
\text { no method for another application referenced. }\end{array}$ & $\mathrm{NO}$ & [53] \\
\hline $\begin{array}{l}\text { Steeb et } \\
\text { al. }\end{array}$ & $\begin{array}{l}\text { Skin Cancer Smartphone Applications for } \\
\text { German-speaking Patients: Review and } \\
\text { Content Analysis Using the Mobile App } \\
\text { Rating Scale }\end{array}$ & 2019 & $\begin{array}{l}\text { Acta Dermato } \\
\text { Venereologica }\end{array}$ & YES & $\mathrm{NO}$ & YES & YES & $\begin{array}{l}\text { Usage of MARS for assessment, no specific method } \\
\text { for the content analysis itself referenced. }\end{array}$ & $\mathrm{NO}$ & [54] \\
\hline $\begin{array}{l}\text { Bardus } \\
\text { et al. }\end{array}$ & $\begin{array}{l}\text { A review and content analysis of } \\
\text { engagement, functionality, aesthetics, } \\
\text { information quality, and change techniques } \\
\text { in the most popular commercial apps for } \\
\text { weight management }\end{array}$ & 2016 & $\begin{array}{l}\text { International } \\
\text { Journal of } \\
\text { Behavioral } \\
\text { Nutrition and } \\
\text { Physical Activity }\end{array}$ & YES & YES & YES & YES & $\begin{array}{l}\text { Usage of MARS for assessment, extensive } \\
\text { documentation of the search results and categories } \\
\text { for coding. Additional calculation of correlation } \\
\text { matrix. }\end{array}$ & $\mathrm{NO}$ & [31] \\
\hline
\end{tabular}


The publications were analyzed based on their title and abstract in the first place and were included in the following deep-dive-evaluation if the abstract referred to the method of content analysis as well as smartphone apps as the objects of analysis.

Concerning identified secondary sources, 30 relevant publications overall were identified. Most of these publications are from the medical sector and contain frameworks from the healthcare sector and analyze medically relevant smartphone apps (e.g., for smoking prevention or fitness). 14 publications do not document any specific method used for the described content analysis and therefore seem to proceed "intuitively" but conclusively, for instance, [26], [27]. 12 publications use or refer to procedures that are similar or at least oriented on classical content analysis procedures. Some of these publications also refer to established standards in the medical field, e.g., the PRISMA Statements for systematic literature reviews or the PPM Precede-Proceed Model, e.g. [28], [29]. Five of these publications use the standard for coding the identified apps, called MARS (Mobile App Rating Scale), developed by [16]; for instance, MARS is used by [30], [31]. MARS contains 6 main categories and 23 subcategories, which focus on the quality of the apps under the premise of providing an easy-to-use and adaptable measurement framework [16]. Four publications did not meet the search criteria. Finally, the strong domain reference to publications in the medical field is particularly noticeable.

Despite the use of referenced procedures, no dedicated method could be identified that represents a re-usable procedure for the content analysis of smartphone apps or provides recommendations for authors. This results in various ambiguities and problems, especially regarding platform specifics, which are expressed by the authors. What could be identified, however, is a standard used for the subsequent categorization of apps (inclusion of general Information, without reference to the researcher's individual research needs). It also originates from the medical field (MARS) and pays special attention to qualitative aspects.

\section{Development of the Method and Assessment Standard}

Since no usable method (without adjustment or optimization for the media type "apps") could be identified during the systematic literature review, an adaptation was conducted based on the available scientific literature. In particular, the special features of smartphone apps were in focus, as highly volatile digital media with a high degree of user interaction. The proposed procedure also integrates the identified standardization approach and is intended to serve as a helpful method guideline for researchers, practitioner, and students.

\subsection{Adaption of a Procedure for Content Analysis}

Several approaches for content analysis were compared, combined, and adapted to the specifics of the media type "smartphone apps" in order to create a new method for supporting the execution of content analysis by eliminating the previously necessary adaptation and transfer tasks. Core components of the proposal method refer to proven procedures of content analysis of traditional media types. In this section, we will focus on special features of smartphone apps. The whole research process is visualized in Figure 1.

Phase 1: Theoretical considerations. Preparations are necessary before implementation. The trigger is usually a concrete research interest of the scientist (in the literature also called "knowledge interest", i.e. the question "What exactly should be investigated?" [21]). This must be concretized by dedicated motivation and precise research questions (scope is here the application of the proposed method by the reader) and sets the basis for the crucial coding frame of the research (dimensions or main categories) [24]. These form a framework for the subsequent research activities and deciding on the concrete procedure. To obtain a broad view of the already existing content of the research, it is necessary to determine the theoretical foundation as well as the current state of research (structured literature review). 


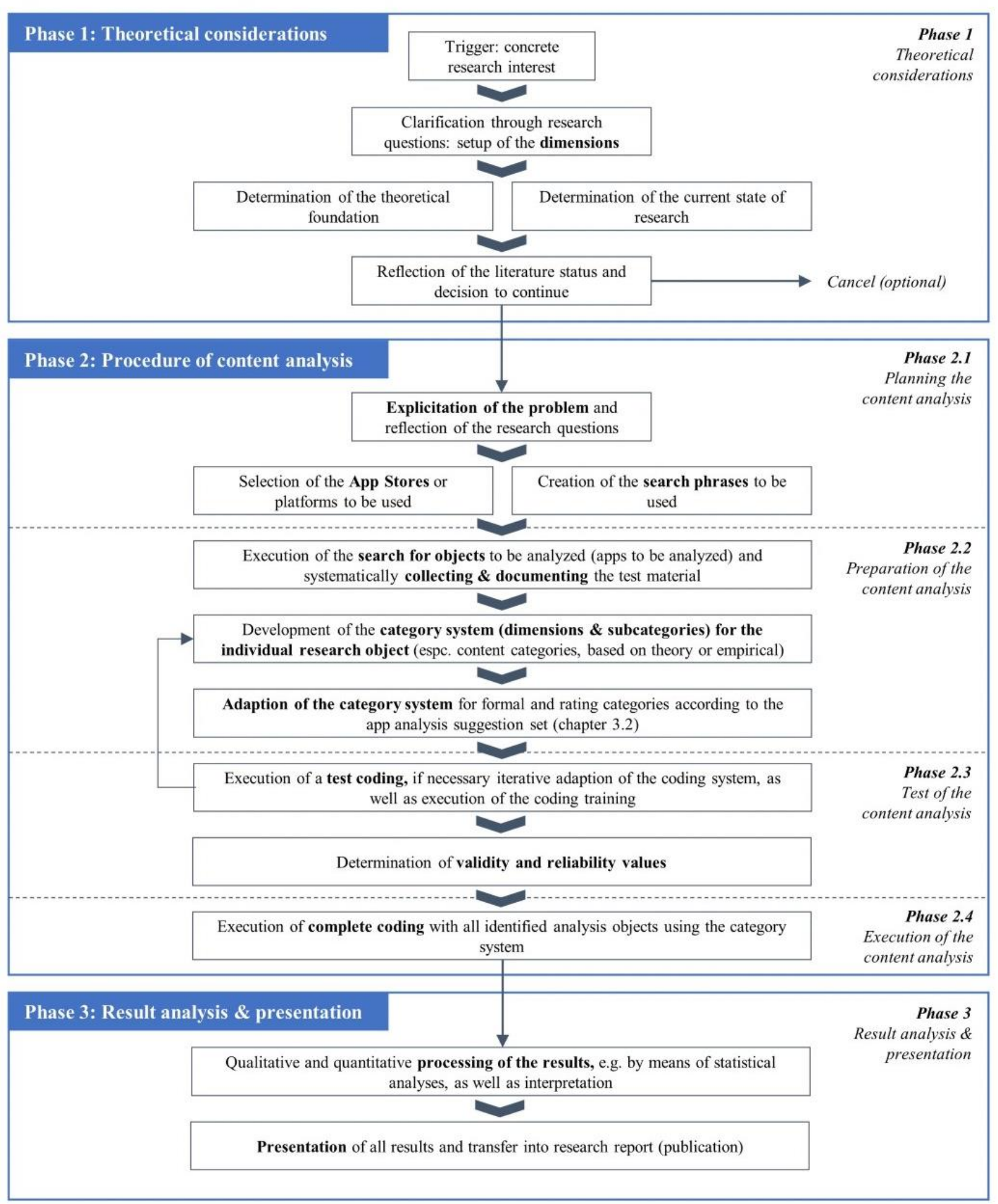

Figure 1. Procedure for content analysis of smartphone apps (oriented on research procedures [8], [9], [21]-[25])

Depending on the content of the research, it is useful to form hypotheses and define terms. Finally, it is advisable to reflect on the current state of the literature to adapt the further procedure if necessary or, if the required information has already been identified by other studies, to terminate the process at this point.

Phase 2.1: Planning the content analysis. Before starting with the actual implementation, the problem definition must be further explained. If necessary, the individual research questions and assumptions made must be reflected upon. This is relevant due to the broadened knowledge base 
of the researcher after the execution of phase 1 and, especially, after an examination of the literature. Usually, different aspects are strengthened by the research needs of other authors; some aspects may already have been answered. This phase ends with the selection of the platforms or app stores to be used and the creation of the search phrases to be used. Regarding the platforms, some special features should be considered first:

- Leading platforms are the Apple App Store and the Google Play Store, according to the current statistics [3]. However, the method itself is generalizable and can be applied to other platforms (with appropriate adjustments in terms of data extraction). For simplicity, we rely on the two leading platforms by Google and Apple.

- The accessibility of the search on the platforms is partly restricted. While the Google Play Store at https://play.google.com/ can be searched using the search phrases, the Apple App Store is only accessible from the end devices (iPhone / iPad) and only reveals apps for the respective device. Via the browser (common access path for corresponding research purposes), help applications such as https://fnd.io/ or https://theappstore.org/ must be accessed, which use of the Apple API. In addition, a country-specific App Store may have to be selected and the same search repeated in several country stores.

Phase 2.2: Preparation of the content analysis. In the preparation phase, two main steps are performed: the search for concrete analysis objects (apps) and the essay of the category system. During the search for apps, it is also advisable to systematically record the test material as a basis for the subsequent refinement through coding. Regarding implementation:

- The displayed items vary depending on the platform (e.g., the Google Play Store does not show the total number of hits). There are differences in the release date and update date, as well as the number of downloads.

- If necessary, the displayed apps are sorted according to a non-publicly accessible algorithm, which prioritizes the items and, if applicable, includes user-specific, individual features. Searches should therefore be carried out and documented as comprehensively as possible.

Concerning the category system, we recommend differentiating:

1. Individual elements of the researcher executing the proposed method, to reflect the research questions. These aspects vary from investigation to investigation. The category system (dimensions, subcategories) needs to be developed for the individual research object. For instance, as in the demonstrational instantiation in Section 4.

2. In addition, a suggested set for app analysis can be adapted. This contains a category system for formal and evaluative rating categories and creates comparability of investigations among themselves. The category system can be used app-agnostic and independent from the individual research topic. This increases the quality of coding and reduces the preparation effort for the researcher.

Phase 2.3 Test of content analysis. Before coding identified apps, so-called test or pilot coding is recommended. This may lead to iterative adjustments to the category system. Together with the test of the quality of the coding (e.g., intercoder reliability), the need for additional training may become apparent.

Phase 2.4 Execution of the content analysis. All preparatory steps are now complete, and the entire set of identified analysis objects can be added to the holistic coding according to the category system. The collected information is recorded by the coders, in the simplest case, supported by an Excel spreadsheet. Due to the challenges in dealing with dynamic online content (apps are subject to similar dynamics), as mentioned by [9], [21], we recommend documentation of the app (e.g., text and images based on the App Store) with the date of access, to be able to reference the presentation available at the corresponding time if necessary. A specific challenge is given by the possibly hidden elements, which are not visible on the platforms based on the description and screenshots [21]. The installation of the app can be a remedy for this, but it requires much more 
time and personnel investment. Furthermore, the use of special apps (e.g., for analyzing the power consumption of households) is sometimes not possible without hardware or access information. Our experience with content analysis based on the demonstrational instantiation of the method (see Section 4) shows that a sufficiently accurate survey of the functions is possible based on screenshots and descriptions of the platforms. If necessary, further information from the developers on separate websites can be integrated. This procedure allows for sufficient analysis accuracy while saving time and bypassing possible installation limitations (for instance, smartphone apps for the use case of the demonstrational instantiation can be used with specific hardware installed in the house or apartment only - which limits the analysis to the usage of screenshots and descriptions). But this may vary from case to case, based on the specifics of the desired app categories as well as on the needed level of granularity of the analysis.

Phase 3: Result analysis \& presentation of the results. Subsequent cleaning and preparation of the results are carried out in a scientific environment, e.g., using software tools for statistical analysis, e.g., SPSS. The following interpretative process creates, in addition to the quantitative presentation of the results, the added value for the final research reports and publications.

\subsection{Derivation of the Generalized Set of Criteria for Evaluation}

In addition, a standard for evaluating apps in the context of content analysis is to be introduced and tested. The whole category set is visualized as Figure 2. The literature describes the following category system classes [21]:

- Formal categories: Concrete facts that can be captured in the process of coding without the coder's room for interpretation. Examples: Name, medium, date, scope, the ranking of the app, genre, or category, etc.

- Content categories: They are used to represent the content focus of the analysis and usually relate directly to the individual, underlying research questions of the researcher executing the proposed method. Examples include topic, existence, and specification of searched functional elements of an app, aspects of the reviews, etc.

- Rating categories: The elements of this category generate the highest differences between the coders in terms of subjectivity. Concerning apps, we speak in particular of user reviews and content-evaluating statements. In addition, overall ratings of the app's suitability for fitting in with the "feel" of the coder are also conceivable (so-called "valence" of a contribution).

Interaction of individual and comparable elements: Only those category system classes that have no direct reference to the individual research content are suitable for adoption. This is confirmed in the context of the limitation of a publication, which states that "for one's research work, category systems from other projects can only be directly adopted if the research question is also identical" [22]. For all other categories, a set of standardized and re-usable elements is helpful to increase the comparability of app analysis studies and to facilitate processing for the researcher.

MARS as a starting point. Within the literature (see Section 2.3), a standard for coding apps has been identified. The so-called MARS (Mobile App Rating Scale) contains six main categories and 23 subcategories and provides a uniform measurement framework. An overview of the elements can be seen in [16], as well as in detail in the corresponding classification template [55]. It is primarily used in medically oriented publications and will be adapted for the evaluation of smartphone apps of any kind in the following. Ideally, the content should be collected without installation, just by using the descriptions and screenshots as well as additional information on developer websites. 
Name of the App (e.g. ABC App)

Provider (company name, e.g. ABC Development Inc.)

Category (depending on App Store, e.g. lifestyle)

Country of origin (e.g. Germany)

Link (to the respective description page within the app store)

App Store (e.g. Google Play Store)

Number of ratings (record separately for each store)

Content categories ( $\mathrm{n}=$ individual, no rating)

Individual research question(s) (RQ) (e.g. presence of a specific functional component, number of research questions depends on the individual research objective (1-n))

Rating categories ( $n=20$, scoring per category \& general)

Relevance of the app (regarding the research questions, analogous to „valence“ within literature)

Commitment

Entertainment * (Is it fun to use the app, does the app supports gamification aspects?)

Interest * (Is the app interesting to use, is the content presented in an engaging way?)

Customization * (Does the app provide all neccessary settings for customization?)

Interactivity * (Is it possible to interact, make user entries, does the app give confirmations?)

Target Group * (Is content \& design of the app adequate for the target group?)

\section{Subjective Qualit:}

Recommendation * (Would the encoder recommend the app for use?)

Usage * (How often would the coder use the app himself in the next 12 months?)

WTP * (Would the encoder pay for this app?)

Overall Rating * (How would the encoder rate the app (star system)?)

\section{Average rating}

Description text (developers details on the app store page)

First release (note: only in the Apple App Store)

Last update (attention: only in the Google Play Store)

Number of installations (attention: only in Google Play Store)

Costs (for first-time installation, no in-app costs) 
Adapted categories for app analysis: Elements taken over from MARS were marked with a "**" in Figure 2. As an additional supplement and support for the content analysis, corresponding test questions were derived to facilitate a subjective answer by the coder. For these elements, the authors suggest a five-level scale. Separate scores are formed for each main category in the evaluation [16], [55]. All five elements were taken from the main category, Commitment. No elements were taken over from the main category Functionality, because installation and use of the app is required. This is shifted to a downstream in-depth analysis of the prioritized apps. From the main category, Aesthetics, all three elements were inherited. Most elements from the main category, Information, were also adopted. By removing the mentioned category Functionality, we have added a new item within this category, complementary to MARS and motivated by the Android Developer Guidelines [56]: Functions, to be able to cover the overall expectation to functional elements and behaviors supplementary to the very specific research questions of the Content Categories. A reduction was made concerning Accuracy of app description, since installation and use are also required here. Furthermore, Evidence base was not adopted since the evidence base is usually not obtained during initial examination, but also requires extensive research as part of the in-depth app analysis. All four elements of the main category App subjective quality were adopted. All elements of the main categories, according to MARS were assigned to the evaluating category since they require a certain degree of subjectivity by the coder. Content categories that directly relate to the individual core of the research are to be created separately and recorded within the framework of the coding.

\section{Evaluation}

\subsection{Use Case: Smart Metering in Germany}

For the evaluation of the adapted method for the content analysis of smartphone apps as well as the adapted rating standard, a demonstrational instantiation based on a real use case is performed. This is especially important for the evaluation of rating categories of an app (see Section 4.2). Its foundation is based on scientific method creation guidelines [19] and was successfully used (after this presented evaluation and with iterative adjustments) in real-life context for the analysis of smartphone apps for smart metering as described in the final report document [58].

The background is the introduction of smart meters (digital, remotely readable electricity meters) or so-called intelligent measuring devices. This rollout is required by law in Germany as part of the energy turnaround, with a gradual implementation and equipping of all households by 2023 [59]. The resulting potentials lie, for instance, in the display of consumption data in realtime, the implementation of new comfort features (notifications of activity in the household, individual device consumption, benchmarking with comparable households), and possible energy savings through timely feedback [60]-[62]. This drastically increases the transparency of private energy consumption and provides customers with a means of controlling costs. Customers are increasingly actively demanding this transparency, partly due to growing ecological awareness [63].

The visualization and analysis of data from smart metering is an essential prerequisite for generating added value. While various possibilities for data acquisition are described in the literature [64], the focus of the following instantiation is on the presentation level of information for the target group of private households. Previous studies have shown (see Section 1) that smartphone apps are a suitable channel for this target group, also, in the application context of energy data evaluation. There are already implementations on the market which are to be examined with the described method for the structured collection of the contained functional components. Therefore, this instantiation has the research goal of identifying functional components of apps in the field of energy data analysis in private households with the aim to validate the designed procedure and rating scheme of Section 3. 


\subsection{Instantiation of the Content Analysis}

The content analysis is carried out using the procedure described in the previous sections to evaluate its suitability:

Phase 1: Theoretical considerations. The concrete research interest lies in the identification of functional components of smartphone apps available on the market to analyze the energy consumption of private households. For the use case explained in Section 4.1 the creation of an initial overview of the state of the art in research and practice is important before building a possible new smartphone app to avoid double work and unnecessary investments. For the described use case it is also interesting to identify possible correlations between features of the apps and the user ratings or perceived satisfaction of the users. Therefore, the creation of a new app can be focused on the most important and helpful features and optimizing customer-centricity, thanks to the initial extraction of the status quo.

Phase 2.1: Planning. For the implementation of the content analysis, both the Apple App Store and the Google Play Store are chosen. For Android, the web version of the Play Store at https://play.google.com/ was used for searching. For iOS, the third-party application https://fnd.io/ was used to find the apps via a browser. The following search phrases have been used: Smart Meter (*), Energy Analyzer, Energy Monitor, Energy Consumption, Energy Consumption, Power Consumption.

Phase 2.2: Preparation. The search terms were used in the Google Play Store one after the other. All displayed apps were checked, and a total of 1,392 hits were reviewed. For iOS, https://fnd.io/ requires the selection of the country store. All search terms were applied to the following stores: US, UK, NL, and DE. The collection of results took place with direct comparison to the list enriched by the Google Play Store and provided 55 new results with a total of 1,079 hits. After performing the search and preliminary check as well as matching between the app stores and cleaning up duplicates, 164 apps remain. Concerning the category system, the proposed subdivision into formal, content, and rating categories was applied. Suggested elements of the formal and rating categories were adopted 1:1. In terms of the content category, five elements were be established for the subcategory Data Acquisition, 24 elements for the subcategory Basic Features, 11 elements for the subcategory Special Features, and five elements for the subcategory "Configuration Options". Each subcategory has received a score (sum of the contained features per app) for evaluation.

Phase 2.3: Test. The apps selected for pre-testing were used to iteratively extend the features of the category system. The sample coding was performed on 40 randomly selected apps of the identified total. Two coders were independently involved in the sample coding. The intercoder reliability was calculated according to Holsti [21] for the formal category is $r=0.99$. It is close to the value of 1 required for formal categories. For the content category, a solid Holsti coefficient of $r=0.87$ on average was determined. Furthermore, Cohen's Kappa was calculated for each element. Of 45 elements, 28 are above the threshold of 0.60, which is considered moderate [21]. For the evaluating category, a Holsti coefficient of $r=0.69$ could be determined, which is low due to the high degree of subjectivity in evaluating categories [21]. The underlying elements are based on the MARS evaluation framework, which has an excellent internal consistency of alpha $=0.9$ [16]. The coding was comprehensively reviewed, with a focus on content elements with low corresponding reliability values.

Phase 2.4: Execution. After performing the search, pre-test, and duplicate cleanup, 164 apps are remaining. Apps that are still being updated and maintained only will be subject to content analysis. The last update (concerning Android versions, most apps are represented in both stores) may therefore be carried out at most one year ago (deadline 01.07.2019). Apps without this Information were kept and further investigated. Overall, there were 133 apps left. Furthermore, only apps that have received a rating above 3 (of 5 stars) from the users (either iOS or Android) 
were the subject to content analysis. Apps that could be too new to receive a rating were still included in the analysis. Apps that have been given a poor rating by users should not be subjected to the analysis to focus on a positive user acceptance and correspondingly involved functional components. There remained 112 apps. Apps identified by secondary literature were added (+3). This resulted in 115 apps for an in-depth analysis according to the set category system.

Phase 3: Processing of results. After successful completion of the content analysis, initial evaluations showed that of 115 apps, only 33 apps had more than 100 ratings (measured by the Google Play Store or Apple App Store) and were therefore subject to active user participation. Seventeen apps had more than 100,000 downloads (measured by Google Play Store) and thus attracted the attention of a wide range of users. The app "EDF \& MOI" from the French energy provider Groupe EDF achieves top values in terms of popularity and user satisfaction. The most functional components (basic features, special features, and configuration options) are realized by the two apps of German origin, "Energy Buddy" and "Powerfox". The application of the MARS evaluation procedure described in Section 3.2 reveals that apps with a correspondingly high rating have an above-average number of functional components (e.g., "Powerfox"), are often new on the market, and are among the outstanding applications. In many cases, these apps are supported by additional media coverage or reviews. The average MARS Total Score is 2.71. Apps with a MARS Total Score above 3.0 (rating: "acceptable" [16]) have an average rating of approx. 4/5 stars. Within this article, a more detailed interpretation of the results and transfer into a dedicated report is not intended and is postponed to a follow-up publication.

\section{Conclusion}

In this article, we describe an adapted method for performing a content analysis for smartphone apps with an associated standardized category set for the evaluation of the identified analysis objects. This provides a suggestion for the stated research question and the need for further research. Subsequently, the method is evaluated by a demonstrational instantiation with a real existing research interest.

The developed procedure is based on instructions of the literature on content analysis in classical media, e.g., newspaper articles. It addresses the lack of a procedure for smartphone apps, which have grown in popularity. The analysis of content and functions of smartphone apps also has an increasing relevance within design-oriented research projects. A systematic approach has not yet been documented in the literature. The documentation of the process saves researchers a considerable amount of transfer effort when adopting a method of traditional content analysis to the context of highly dynamic media such as apps. In addition, the proposed set of criteria provides a basis for comparability across multiple analyses. In particular, the special features of App Stores as necessary platforms for the search process are discussed, which, when carried out for the first time, generate high research and testing effort for the researcher and, also, cause different problems and resulting limitations mentioned in the identified literature. Previous publications about content analysis with apps either proceed without an explicit method or use approaches from the medical field. Furthermore, different procedures have been used for the evaluation of the identified objects - again, many in the context of medical publications only.

The evaluation of the method has demonstrated the feasibility and led to small, iterative adjustments in the descriptions. Thus, the procedure could be guided, run through quickly and efficiently, and its focus was placed on the content of the coding. The first results of the MARS Score, which have shown the identified apps were suitable based on the assessment of the coders, also prove themselves in practice. This is evident from the above-average user ratings. In addition, the apps with high scores show an above-average number of features and are also, on average, newer apps. The MARS framework was assigned exclusively to the evaluating categories and revised in advance. Therefore, a time-saving extraction is possible using the documentation provided by the app developer (description text and screenshots, without the need to install the app, which is not always possible due to access restrictions). The proposed method offers a useful 
standard for the rating of the identified apps, which facilitates comparison with other app analysis and publications. During the instantiation process, the questions could be answered easily by the coders.

Based on the performed instantiation, the described method could be successfully tested and iteratively improved. As a result, it can be used for further investigations. The identified category set for the evaluation of apps was adapted, and also used, outside the domain of medical publications. Based on the first evaluation the method serves to increase the comparability of app analysis. In the following investigations, an intensive examination of the content components of the research object of the evaluation will take place. This will contain an adequate analysis, interpretation, and transfer of the results in a separate research report with the goal to identify which subcategory (a feature of the app) causes the highest degree of usage and satisfaction among users and how this interacts with the previous assessments of the coders.

\section{References}

[1] Statista, "Smartphone penetration rate by country 2020," Statista. https://www.statista.com/statistics/539395/smartphone-penetration-worldwide-by-country/. Accessed on Oct. $1,2021$.

[2] Statista, "Number of smartphone users in Germany by 2019," 2020. https://de.statista.com/statistik/daten/studie/198959/umfrage/anzahl-der-smartphonenutzer-in-deutschlandseit-2010/. Accessed on Aug. 15, 2020.

[3] Statista, "Number of apps available in leading app stores as of 1st quarter 2021," Statista. https://www.statista.com/statistics/276623/number-of-apps-available-in-leading-app-stores/. Accessed on Oct. $1,2021$.

[4] J. Jung, R. Bapna, J. Ramaprasad, and A. Umyarov, "Love Unshackled: Identifying the Effect of Mobile App Adoption in Online Dating," MIS Quarterly, vol. 43, no. 1, pp. 47-72, Jan. 2019. Available: https://doi.org/10.25300/MISQ/2019/14289

[5] J. Manlove and B. Whitacre, "Understanding the trend to mobile-only internet connections: A decomposition analysis," Telecommunications Policy, vol. 43, no. 1, pp. 76-87, Feb. 2019. Available: https://doi.org/10.1016/j.telpol.2018.03.012

[6] M. J. Noh and K. T. Lee, "An analysis of the relationship between quality and user acceptance in smartphone apps," Inf Syst E-Bus Manage, vol. 14, no. 2, pp. 273-291, May 2016. Available: https://doi.org/10.1007/s10257-015-0283-6

[7] D. Wang, S. Park, and D. Fesenmaier, “An examination of information services and smartphone applications," 2011.

[8] N. Baur and J. Blasius, Eds., Handbuch Methoden der empirischen Sozialforschung, 2., Vollständig überarbeitete und erweiterte Auflage. Wiesbaden: Springer VS, 2019, (in German). https://doi.org/10.1007/978-3-65821308-4

[9] K. A. Neuendorf, The content analysis guidebook, Second edition. Los Angeles: SAGE, 2017. https://doi.org/10.4135/9781071802878

[10] A. R. Hevner, S. T. March, J. Park, and S. Ram, "Design Science in Information Systems Research,” MIS Quarterly, vol. 28, no. 1, pp. 75-105, 2004. Available: https://doi.org/10.2307/25148625

[11] J. Venable, “A framework for design science research activities,” Proceedings of the 2006 Information Resource Management Association Conference, pp. 184-187, Jan. 2006.

[12] K. Peffers, T. Tuunanen, M. A. Rothenberger, and S. Chatterjee, “A Design Science Research Methodology for Information Systems Research,” Journal of Management Information Systems, vol. 24, no. 3, pp. 45-77, Dec. 2007. Available: https://doi.org/10.2753/MIS0742-1222240302

[13] A. Dresch, D. P. Lacerda, and J. A. V. Antunes Jr, Design Science Research: A Method for Science and Technology Advancement. Cham: Springer International Publishing, 2015. Available: https://doi.org/10.1007/978-3-319-07374-3

[14] E. Cummings, E. Borycki, and E. Roehrer, "Issues and considerations for healthcare consumers using mobile applications," Studies in health technology and informatics, vol. 183, pp. 227-231, Feb. 2013. Available: https://doi.org/10.3233/978-1-61499-203-5-227 
[15] S. M. Coulon, C. M. Monroe, and D. S. West, "A Systematic, Multi-domain Review of Mobile Smartphone Apps for Evidence-Based Stress Management," American Journal of Preventive Medicine, vol. 51, no. 1, pp. 95-105, Jul. 2016. Available: https://doi.org/10.1016/j.amepre.2016.01.026

[16] S. R. Stoyanov, L. Hides, D. J. Kavanagh, O. Zelenko, D. Tjondronegoro, and M. Mani, "Mobile App Rating Scale: A New Tool for Assessing the Quality of Health Mobile Apps," JMIR Mhealth Uhealth, vol. 3, no. 1, p. e27, Mar. 2015. Available: https://doi.org/10.2196/mhealth.3422

[17] M. Kuehnhausen and V. S. Frost, "Trusting smartphone Apps? To install or not to install, that is the question," CogSIMA 2013, San Diego, pp. 30-37, Feb. 2013. Available: https://doi.org/10.1109/CogSIMA.2013.6523820

[18] A. Girardello and F. Michahelles, “AppAware: which mobile applications are hot?" MobileHCI 2010 Conference, Lisbon, pp. 431-434, 2010. Available: https://doi.org/10.1145/1851600.1851698

[19] P. Smith and D. K. Apple, Methodology for Creating Methodologies, 2006.

[20] A. Sunyaev, M. Hansen, and H. Krcmar, "Method Engineering: A Formal Description," in Information Systems Development, G. A. Papadopoulos, W. Wojtkowski, G. Wojtkowski, S. Wrycza, and J. Zupancic, Eds. Boston, MA: Springer US, pp. 645-654, 2009. Available: https://doi.org/10.1007/b137171_67

[21] P. Rössler, Inhaltsanalyse, 3. Auflage. Konstanz: UVK Verlagsgesellschaft mbH, 2017, (in German). Available: https://elibrary.utb.de/action/doSearch?AllField=9783838547060\&. Accessed on July 16, 2020.

[22] W. Früh, Inhaltsanalyse: Theorie und Praxis, 9., Überarbeitete Auflage. Konstanz: UVK Verlagsgesellschaft $\mathrm{mbH}, 2017$.

[23] K. Krippendorff, Content analysis: an introduction to its methodology, 2nd ed. Thousand Oaks, Calif: Sage, 2004.

[24] M. Schreier, Qualitative content analysis in practice. Los Angeles: SAGE, 2012.

[25] J. W. Drisko and T. Maschi, Content analysis. New York: Oxford University Press, 2016. https://doi.org/10.1093/acprof:oso/9780190215491.001.0001

[26] L. C. Abroms, J. Lee Westmaas, J. Bontemps-Jones, R. Ramani, and J. Mellerson, “A Content Analysis of Popular Smartphone Apps for Smoking Cessation," American Journal of Preventive Medicine, vol. 45, no. 6, pp. 732-736, Dec. 2013. Available: https://doi.org/10.1016/j.amepre.2013.07.008

[27] B. B. Hoeppner, M. R. Schick, L. M. Kelly, S. S. Hoeppner, B. Bergman, and J. F. Kelly, “There is an app for that - Or is there? A content analysis of publicly available smartphone apps for managing alcohol use," Journal of Substance Abuse Treatment, vol. 82, pp. 67-73, Nov. 2017. Available: https://doi.org/10.1016/j.jsat.2017.09.006

[28] K. Hotwani, K. Sharma, D. Nagpal, G. Lamba, and P. Chaudhari, "Smartphones and tooth brushing: content analysis of the current available mobile health apps for motivation and training," Eur Arch Paediatr Dent, vol. 21, no. 1, pp. 103-108, Feb. 2020, Available: https://doi.org/10.1007/s40368-019-00457-1

[29] A. H. Qari, “Assessing the quality of mobile apps for oral health: content analysis and usability,” 2020.

[30] G. C. Machado et al., "Smartphone apps for the self-management of low back pain: A systematic review," Best Practice \& Research Clinical Rheumatology, vol. 30, no. 6, pp. 1098-1109, Dec. 2016. Available: https://doi.org/10.1016/j.berh.2017.04.002

[31] M. Bardus, S. B. van Beurden, J. R. Smith, and C. Abraham, "A review and content analysis of engagement, functionality, aesthetics, information quality, and change techniques in the most popular commercial apps for weight management," Int J Behav Nutr Phys Act, vol. 13, no. 1, p. 35, Dec. 2016. Available: https://doi.org/10.1186/s12966-016-0359-9

[32] T. Alessa, M. S. Hawley, E. S. Hock, and L. de Witte, "Smartphone Apps to Support Self-Management of Hypertension: Review and Content Analysis,” JMIR Mhealth Uhealth, vol. 7, no. 5, p. e13645, May 2019. Available: https://doi.org/10.2196/13645

[33] K. M. J. Azar et al., "Mobile Applications for Weight Management," American Journal of Preventive Medicine, vol. 45, no. 5, pp. 583-589, Nov. 2013. Available: https://doi.org/10.1016/j.amepre.2013.07.005

[34] D. Bowie-DaBreo, S.-I. Sunram-Lea, and C. Sas, “A content analysis and ethical review of mobile applications for depression: Exploring the app marketplace." $2019 . \quad$ Available: http://www.research.lancs.ac.uk/portal/en/publications/a-content-analysis-and-ethical-review-of-mobileapplications-for-depression(b7d0bea7-74d0-4fe1-98cf-113a43054d4e).html

[35] L. J. Bry, T. Chou, E. Miguel, and J. S. Comer, “Consumer Smartphone Apps Marketed for Child and Adolescent Anxiety: A Systematic Review and Content Analysis," Behavior Therapy, vol. 49, no. 2, pp. 249-261, Mar. 2018. Available: https://doi.org/10.1016/j.beth.2017.07.008 
[36] G. Ferriero, L. Longoni, and R. Brunati, "Apps for smartphone available through distribution platforms and validated for goniometric measurement: A systematic review," Annals of Physical and Rehabilitation Medicine, vol. 61, pp. e445-e446, Jul. 2018. Available: https://doi.org/10.1016/j.rehab.2018.05.1037

[37] J. Linardon, "Can Acceptance, Mindfulness, and Self-Compassion Be Learned by Smartphone Apps? A Systematic and Meta-Analytic Review of Randomized Controlled Trials," Behavior Therapy, vol. 51, no. 4, pp. 646-658, Jul. 2020. Available: https://doi.org/10.1016/j.beth.2019.10.002

[38] L. Maxwell, A. Sanders, J. Skues, and L. Wise, “A Content Analysis of Personal Safety Apps: Are They Keeping Us Safe or Making Us More Vulnerable?” Violence Against Women, vol. 26, no. 2, pp. 233-248, Feb. 2020. Available: https://doi.org/10.1177/1077801219832124

[39] A. Middelweerd, J. S. Mollee, C. N. van der Wal, J. Brug, and S. J. te Velde, “Apps to promote physical activity among adults: a review and content analysis," Int J Behav Nutr Phys Act, vol. 11, no. 1, p. 97, Dec. 2014. Available: https://doi.org/10.1186/s12966-014-0097-9

[40] C. Shuler, "A Content Analysis of the iTunes App Store's Education Section." 2009. Available: https://www.joanganzcooneycenter.org/wp-content/uploads/2010/03/ilearn_1_.pdf. Accessed on May 8, 2020.

[41] A. Tham, L. Kim, S. Victory, Y. Chen, K. Zheng, and E. V. Eikey, "A content analysis of popular diet, fitness, and weight self-tracking mobile apps on Google Play," iConference 2020 Proceedings, 2020. Available: https://www.ideals.illinois.edu/handle/2142/106581

[42] D. H. Charbonneau et al., "Smartphone apps for cancer: A content analysis of the digital health marketplace," DIGITAL HEALTH, vol. 6, Jan. 2020. Available: https://doi.org/10.1177/2055207620905413

[43] J. H. West, P. C. Hall, C. L. Hanson, M. D. Barnes, C. Giraud-Carrier, and J. Barrett, “There's an App for That: Content Analysis of Paid Health and Fitness Apps," J Med Internet Res, vol. 14, no. 3, p. e72, May 2012. Available: https://doi.org/10.2196/jmir.1977

[44] S. Zaidan and E. Roehrer, "Popular Mobile Phone Apps for Diet and Weight Loss: A Content Analysis," JMIR Mhealth Uhealth, vol. 4, no. 3, p. e80, Jul. 2016. Available: https://doi.org/10.2196/mhealth.5406

[45] L. Fernandez-Luque, J. I. Labarta, E. Palmer, and E. Koledova, "Content Analysis of Apps for Growth Monitoring and Growth Hormone Treatment: Systematic Search in the Android App Store," JMIR Mhealth Uhealth, vol. 8, no. 2, p. e16208, Feb. 2020. Available: https://doi.org/10.2196/16208.

[46] J. Nicholas, A. S. Fogarty, K. Boydell, and H. Christensen, “The Reviews Are in: A Qualitative Content Analysis of Consumer Perspectives on Apps for Bipolar Disorder," J Med Internet Res, vol. 19, no. 4, p. e105, Apr. 2017. Available: https://doi.org/10.2196/jmir.7273

[47] H. E. Payne, J. Wilkinson, J. H. West, and J. M. Bernhardt, "A content analysis of precede-proceed constructs in stress management mobile apps," Mhealth, vol. 2, no. 2, Feb. 2016. Available: https://doi.org/10.3978/j.issn.2306-9740.2016.02.02

[48] C. D. Robinson et al., “A content analysis of smartphone apps for adolescent smoking cessation,” Translational Behavioral Medicine, vol. 10, no. 1, pp. 302-309, Feb. 2020. Available: https://doi.org/10.1093/tbm/iby113

[49] N. Shen et al., "Finding a Depression App: A Review and Content Analysis of the Depression App Marketplace," JMIR Mhealth Uhealth, vol. 3, no. 1, p. e16, Feb. 2015. Available: https://doi.org/10.2196/mhealth.3713

[50] A. R. Wasil, K. E. Venturo-Conerly, R. M. Shingleton, and J. R. Weisz, “A review of popular smartphone apps for depression and anxiety: Assessing the inclusion of evidence-based content," Behaviour Research and Therapy, vol. 123, Dec. 2019. Available: https://doi.org/10.1016/j.brat.2019.103498

[51] Y. Xu and M. Warschauer, "A Content Analysis of Voice-based Apps on the Market for Early Literacy Development," IDC '20: Proceedings of the Interaction Design and Children Conference, pp. 361-371, 2020. https://doi.org/10.1145/3392063.3394418

[52] R. Biviji, J. R. Vest, B. E. Dixon, T. Cullen, and C. A. Harle, "Content analysis of behavior change techniques in maternal and infant health apps," Translational Behavioral Medicine, vol. 11, no. 2, pp. 504-515, Jun. 2020. Available: https://doi.org/10.1093/tbm/ibaa039

[53] J. Lee et al., "A content analysis of free smoking cessation mobile applications in the USA,” Journal of Smoking Cessation, vol. 14, no. 4, pp. 195-202, 2019. Available: https://doi.org/10.1017/jsc.2019.6

[54] T. Steeb, A. Wessely, L. French, M. Heppt, and C. Berking, "Skin Cancer Smartphone Applications for Germanspeaking Patients: Review and Content Analysis Using the Mobile App Rating Scale," Acta Derm Venerol, vol. 99, no. 11, pp. 1043-1044, 2019. Available: https://doi.org/10.2340/00015555-3240

[55] S. R. Stoyanov, L. Hides, D. J. Kavanagh, O. Zelenko, D. Tjondronegoro, and M. Mani, "Mobile App Rating Scale: A New Tool for Assessing the Quality of Health Mobile Apps Multimedia Appendix 2 (Mobile App Rating Scale)." $2015 . \quad$ Available: 
https://www.ncbi.nlm.nih.gov/pmc/articles/PMC4376132/bin/mhealth_v3i1e27_app2.pdf. Accessed on Aug. 7, 2020.

[56] Google, “Android Developer Guidelines: Core app quality,” 2021. https://developer.android.com/docs/qualityguidelines/core-app-quality?hl=de. Accessed on Oct. 1, 2021.

[57] Apple, “Apple iOS Human Interface Developer Guidelines,” 2021. https://developer.apple.com/design/humaninterface-guidelines/ios/overview/themes/. Accessed on Oct. 1, 2021.

[58] T. Weiß and S. Strahringer, "Inhaltliche Analyse von Smartphone-Apps zur Auswertung des Stromverbrauchs privater Endverbraucher," Z Energiewirtsch, vol. 45, no. 3, pp. 227-244, Sep. 2021, (in German). Available: https://doi.org/10.1007/s12398-021-00306-z

[59] Bundesnetzagentur, "Messeinrichtungen / Zähler," 2020, (in German). https://www.bundesnetzagentur.de/DE/Sachgebiete/ElektrizitaetundGas/Verbraucher/Metering/SmartMeter_n ode.html. Accessed on Aug. 26, 2021.

[60] EON, "Smart Meter Pflicht: Intelligente Stromzähler," 2020. https://www.eon.de/de/eonerleben/smart-meterpflicht-in-deutschland.html. Accessed on Aug. 26, 2021.

[61] D. Fox, “Smart Meter,” Datenschutz und Datensicherheit - DuD, vol. 34, no. 6, p. 408, Jun. 2010, (in German). Available: https://doi.org/10.1007/s11623-010-0115-2

[62] C. Müller-Elschner, "Die Rolle von Informations - und Kommunikationstechnologie beim Smart Metering," in Smart Metering: Technologische, wirtschaftliche und juristische Aspekte des Smart Metering, Ks-EnergyVerlag., Berlin: Köhler-Schute, C., 2010.

[63] D. C. Fettermann, C. G. S. Cavalcante, N. F. Ayala, and M. C. Avalone, "Configuration of a smart meter for Brazilian customers," Energy Policy, vol. 139, Apr. 2020, Available: https://doi.org/10.1016/j.enpol.2020.111309

[64] C. Aichele and O. D. Doleski, Eds., Smart Meter Rollout. Wiesbaden: Springer Fachmedien Wiesbaden, 2013, (in German). Available: https://doi.org/10.1007/978-3-8348-2440-0 